$1-1-1955$

\title{
The Effect of Rate and Frequency of Phosphate Application on Pasture Production
}

Frank W. Schaller

G. G. Pohlman

Follow this and additional works at: https://researchrepository.wvu.edu/ wv_agricultural_and_forestry_experiment_station_bulletins

\section{Digital Commons Citation}

Schaller, Frank W. and Pohlman, G. G., "The Effect of Rate and Frequency of Phosphate Application on Pasture Production" (1955). West Virginia Agricultural and Forestry Experiment Station Bulletins. 380.

https://researchrepository.wvu.edu/wv_agricultural_and_forestry_experiment_station_bulletins/371 @ WVU. It has been accepted for inclusion in West Virginia Agricultural and Forestry Experiment Station Bulletins by an authorized administrator of The Research Repository @ WVU. For more information, please contact ian.harmon@mail.wvu.edu. 

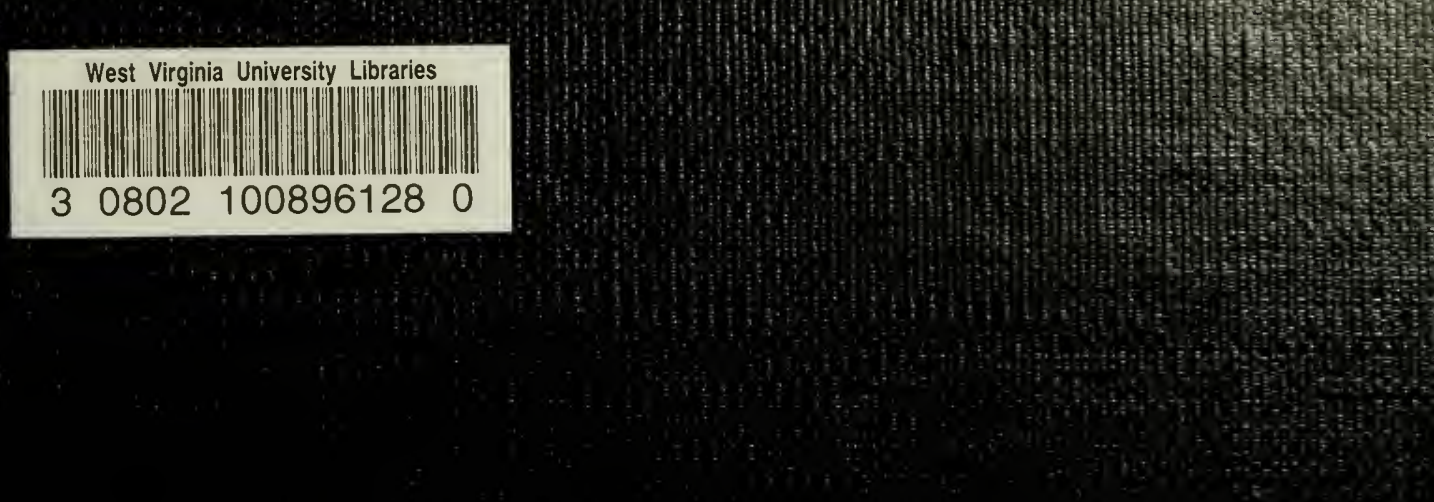


\section{Digitized by the Internet Archive in 2010 with funding from \\ Lyrasis Members and Sloan Foundation}




\section{BULLETIN 380}

June 1955

The Effect of Rate and Frequency of Phosphate Application on Pasture Production 


\section{Summary and Conclusions}

The results of a study of rate and frequency of phosphate application to permanent pastures are reported. The results indicate little difference in yield associated with frequency of application. However, yields are directly related to the rate of application. In these experiments the use of at least 40 pounds of $\mathrm{P}_{2} \mathrm{O}_{5}$ per acre per year (200 pounds of 20 per cent superphosphate) gave the most profitable increases in two of the three tests and only slightly lower returns in the third test. In the latter case the tests were conducted for seven years instead of eight. This may be partly responsible for the lower relative return.

The greatest increase in yield usually occurred in the second and third years after application. However, yields were influenced by available moisture. At Wardensville the most notable response to the initial application did not occur until the sixth year, a year with very favorable rainfall.

Liming to $\mathrm{pH} 6.0$ resulted in a significant increase in yield on the plots at Hurricane but had no effect on the limestone soil at Lewisburg. Additional lime above $\mathrm{pH} 6.0$ had little effect at Wardensville.

The highest rate of application of superphosphate $\left(40\right.$ pounds $\mathrm{P}_{2} \mathrm{O}_{5}$ or 200 pounds of 20 per cent superphosphate per acre per year) gave the most profitable increase at Lewisburg and Wardensville. At Hurricane the most profitable increase was from an initial application of 1,200 pounds of superphosphate. However, it should be noted that the yields at Hurricane were only for seven years.

West Virginia University

Agricultural Experiment Station

College of Agriculture, Forestry, and Home Economics

H. R. VARNEY, DiRECTOR

MORGANTOWN 


\section{The Effect of Rate and Frequency of Phosphate Application on Pasture Production}

\section{Introduction}

F. W. SCHALLER and G. G. POHLMAN *

SURVEY of pasture conditions in West Virginia in 1935 (1) revealed that 85 per cent of the pastures studied needed lime and that 94 per cent were low in available phosphate. Fertilizer trials $(2,3,4)$ on pastures showed good response to applications of both lime and phosphate. The response was evident in both yield and quality of the herbage produced. As a result, applications of lime and superphosphate have come to be recognized as basic treatments in the improvement of permanent pasture in West Virginia.

The experimental work reported here was started in 1939 primarily to obtain information on yield and botanical composition of pastures as affected by (a) the rate of application and (b) the frequency of application of superphosphate. Additional plots were included to give further evidence on the influence of lime, potash, and time of fertilizer application on yield and quality of pasture vegetation.

\section{The Experiments}

The experiment was conducted at three locations: The Reymann Memorial Farms, near Wardensvilie in Hardy County, on Litz silt loam; the Waters farm, near Lewisburg in Greenbrier County, on Frankstown silt loam; and the Jordan farm, near Hurricane in Putnam County, on Vincent silt loam. The plots were 1/500-acre, and each treatment was replicated four times at random. Surface applications of lime and fertilizer were made in the fall except on those plots used for the comparison of time of application of lime and superphosphate. Initial applications were made in 1939.

The plots were clipped with a lawn mover set at $13 / 8$ inches. Cuttings were made at approximately monthly intervals. From 1940 to 1943,

NOTE : The authors wish to express their appreciation to R. M. Smith, formerly Soil Scientist, Soil Conservation Service, and now Superintendent, Temple Substation, Temple, Texas, and to D. R. Browning, formerly Assistant Soil Scientist, Soii Conservation Service and now Assistant Agronomist in charge, Ohio Valley Substation, Point Pleasant, West Virginia.

*F. W. Schaller, formerly Assistant Agronomist and Assistant Professor of Agronomy; G. G. Pohlman is Agronomist and Professor and Head of Agronomy and Genetics. 
the entire plot was harvested for yield. In later years, two 15-inch lawn mower swaths were removed, and the remainder was mowed and left on the plot. The dry weight of clipped herbage was determined and is reported in pounds per acre. Estimates of the amount of cover consisting of various species were made in the spring and fall of each year. The percentage of this cover consisting of bluegrass, red top, orchard grass, timothy, white clover, red clover, hop clover, and lespedeza is reported as desirable species. Bluegrass and white clover were usually the predominant desirable species.

\section{Influence of Rainfall on Results}

Both yield and response to treatment were influenced by rainfall, particularly the moisture available during the growing season. The relationship between rainfall during the growing season (April to October 1) and yield of untreated plots is given in Table 1.

Table 1. The Relationship Between Rainfall During the Growing Season (April to October) and Yield of Untreated Pasture Plots

\begin{tabular}{|c|c|c|c|c|c|c|}
\hline \multirow{3}{*}{ YF,AR } & \multicolumn{6}{|c|}{ LOCATION } \\
\hline & \multicolumn{2}{|c|}{ HURRICANE } & \multicolumn{2}{|c|}{ LEWISBURG } & \multicolumn{2}{|c|}{ WARDENSVILLE } \\
\hline & RAINFALL & YIELD & RAINFALL & YIELD & RAINFALL & YIELD \\
\hline & Inches & $L b s$ & Inches & $L b s$ & Inches & $L b s$ \\
\hline 1940 & 22.2 & 1029 & 27.4 & 2001 & 27.8 & 1343 \\
\hline 1941 & 23.0 & 1128 & 16.3 & 1347 & 19.6 & 727 \\
\hline 1942 & 26.3 & 1190 & 28.3 & 1995 & 31.3 & 603 \\
\hline 1943 & 25.5 & 1058 & 18.8 & 1632 & 18.0 & 645 \\
\hline 1944 & 24.4 & 350 & $2 \mathbf{i} .0$ & 866 & 24.1 & 509 \\
\hline $1945 \ldots \ldots . . . .$. & 21.4 & 631 & 22.6 & 1864 & 30.8 & 842 \\
\hline $1946 \ldots \ldots . . . .$. & 26.3 & $743 * *$ & 20.3 & 1259 & 18.6 & 580 \\
\hline 1947 & 27.5 & & 21.5 & 566 & 17.7 & 272 \\
\hline Average.. & 24.5 & 876 & 22.0 & 1441 & 23.5 & 690 \\
\hline Normal .. & 24.7 & & 24.2 & & 21.0 & \\
\hline
\end{tabular}

* Rainfall data are for Huntington, the nearest weather station.

* First clipping (growth to May 9) lost.

The data in Table 1 show that rainfall at Huntington was about normal in all years. In 1944 and 1945 yields were low. This appears to be related to low rainfall during June, July, and August. The apparent low yield in 1946 was due to the loss of May 9 cutting.

Yields at Lewisburg show a rather wide variation, with high yields being obtained in 1940, 1942, and 1945, and low yields in 1944 and 1947. The high yields were secured in the years with the highest rainfall during the growing season. Low yields in 1944 and 1947 were associated with below average rainfall, especially during the spring and early summer.

The yields at Wardensville were affected markedly by rainfall distribution. The data show four years with above average rainfall. Two 
of these, 1940 and 1945, are the years showing highest yields of check plots. In both of these years, rainfall was above normal for most of the season. In 1942 and 1944, the other years with above average rainfall, there were extended dry periods which reduced growth. The rainfall was below average during the other four years and yields were low. As a result, response to treatment at Wardensville was considerably less than at either of the other two locations. Furthermore, as will be noted later, the effect of treatment did not become marked until 1945, the year with most favorable moisture distribution.

\section{Effect of Superphosphate}

\section{RATE OF APPLICATION}

As a part of the experiment, 20 per cent superphosphate was applied in the fall of 1939 at rates of 400,800 , and 1,200 pounds per acre. These applications were made on plots which were limed or had a $\mathrm{pH}$ of at least 6.0. No additional fertilizer was added to these plots after the initial application. The results for the three locations are given in Figure 1.

These results show a consistent increase in yield and desirable plant species as the rate of superphosphate was increased. At Lewisburg and Hurricane, the greatest increase in yield was for the second 400 -pound increment ( 800 pounds over 400 pounds), whereas at Wardensville, it was for the third increment (1,200 pounds over 800 pounds). This may have been the result of fixation of phosphorus during the early years when response was limited by dry weather.

YIELO

DEsIRABLE SPECIES

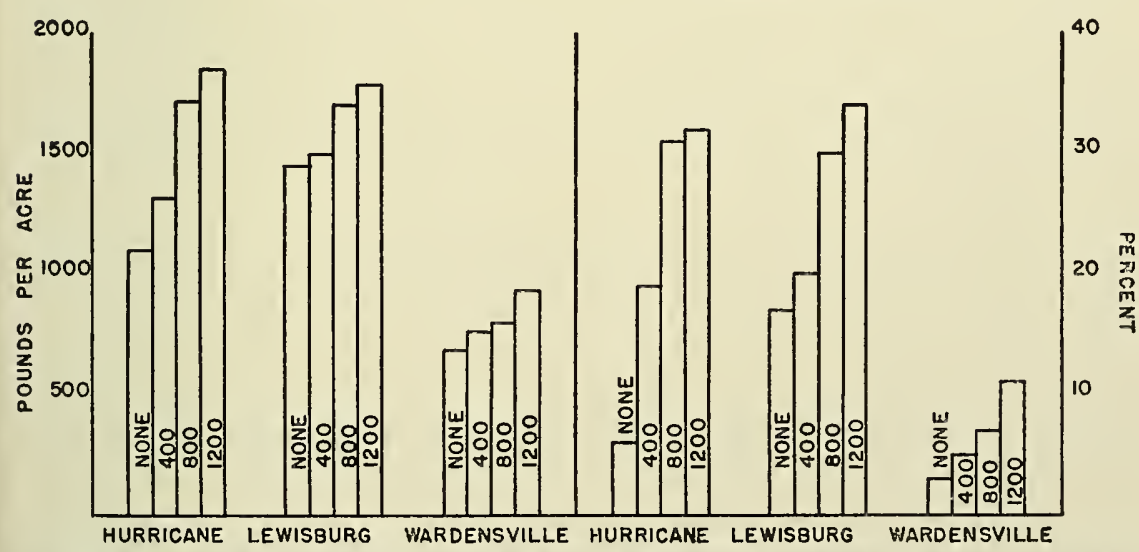

FIGURE 1. Effect of varying initial applications of 20 per cent superphosphate on average yields and desirable species of permanent pastures. 
Averaging the results of all three locations, the increases in yield for the various applications are as follows:

$$
\begin{array}{rlll}
400 & \text { lbs. } & \ldots \ldots \ldots & 13.4 \% \\
800 & \text { lbs. } & \ldots \ldots & 31.6 \% \\
1200 & \text { lbs. } & \ldots \ldots & 42.4 \%
\end{array}
$$

The response by years for the three treatments in the three areas is given in Figure 2.

$$
\text { HURRICANE LEWISBURG WARDENSVILLE }
$$

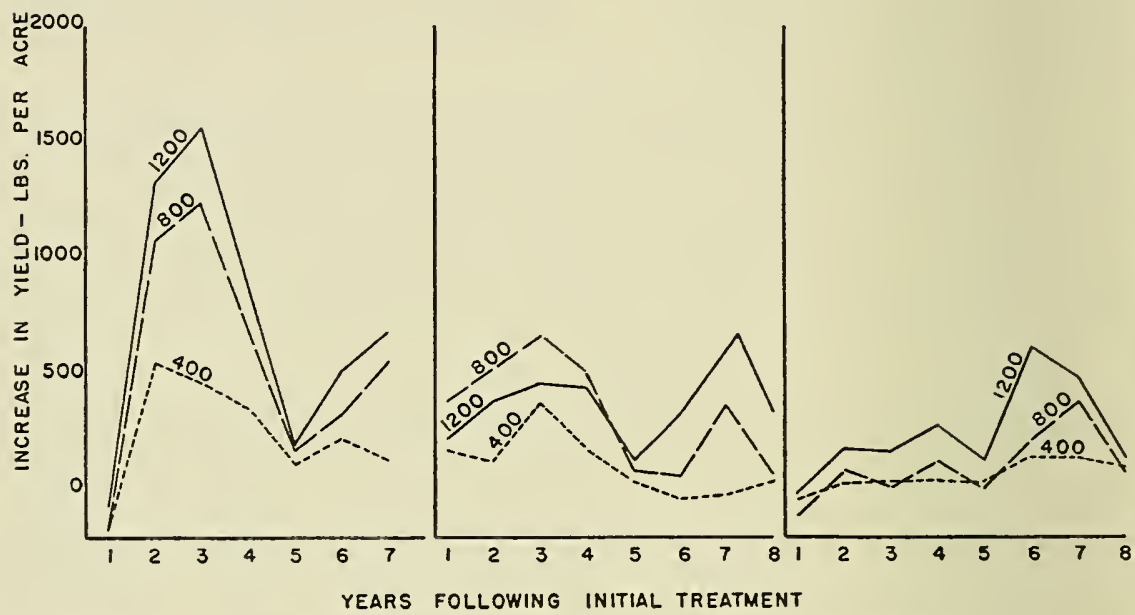

FIGURE 2. Increase in yield of forage resulting from surface application of 20 per cent superphosphate made in the fall of 1939.

These results show, in general, that the higher the initial application the greater the yield throughout the test. At Lewisburg for the first four years, the apparent difference in yield between the 800- and 1,200pound applications was within experimental error and is attributed to plot variation.

At both Hurricane and Lewisburg, the greatest increase in yield was secured in 1942, the third year after application and a year with favorable rainfall distribution at both locations. The total yield and increase from treatment then declined, especially in 1944, a season with unfavorable rainfall at all locations. Treatment effects, especially from the higher rates of phosphate, again showed marked effects in 1945 and 1946. In fact, these were the first years phosphate treatment at Wardensville brought about an increase in white clover. These increases were associated with moisture conditions favorable for pasture grasses and legumes. 


\section{FREQUENCY OF APPLICATION OF SUPERPHOSPHATE}

The effect of frequency of application of superphosphate to permanent pastures was tested at three levels of phosphate application. These will be considered as low, medium, and high.

\section{AT LOW PHOSPHATE LEVELS}

Superphosphate was applied in amounts to give an average of 50 pounds of 20 per cent superphosphate (10 pounds $\mathrm{P}_{2} \mathrm{O}_{5}$ ) per acre per year. It was applied in two ways: (a) 200 pounds every four years and (b) 400 pounds every eight years. The results compared to untreated plots are given in Figure 3.

YIELD

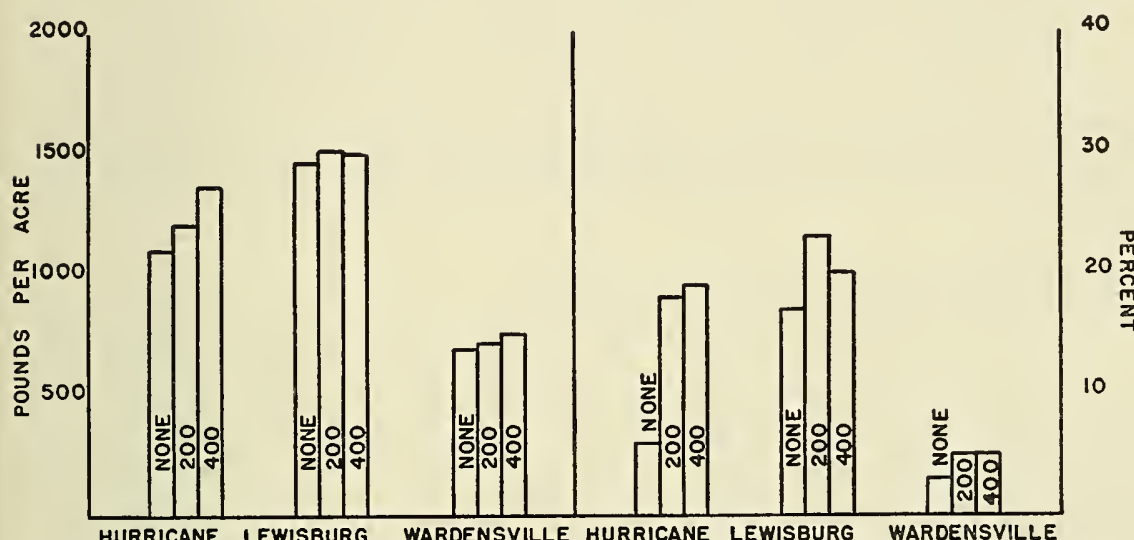

FIGURE 3. Effect of frequency of application of low rates of 20 per cent superphosphate on yield and desirable species in permanent pastures. Rates were none, 200 pounds every 4 years, and 400 pounds as initial application.

The results show only a small effect of these low rates of phosphate application on either yield or desirable species. In only one comparison, no phosphorus vs. 400 pounds every eight years at Hurricane was the yield difference above probable error. The difference between the two frequencies of application was too small to be significant. The largest difference was on the plots at Hurricane, which may be partly due to the fact that the results are for seven instead of eight years.

Study of yields by years indicates a noticeable difference in distribution. The general trend is shown in Figure 4 for each of the areas. These data show there was little response for the first 200-pound application but a marked increase in 1945, the second year after the second 200-pound increment was applied. The effect of the 400-pound application varied with location and season but usually gave a good increase in yield during the first favorable season after application. 


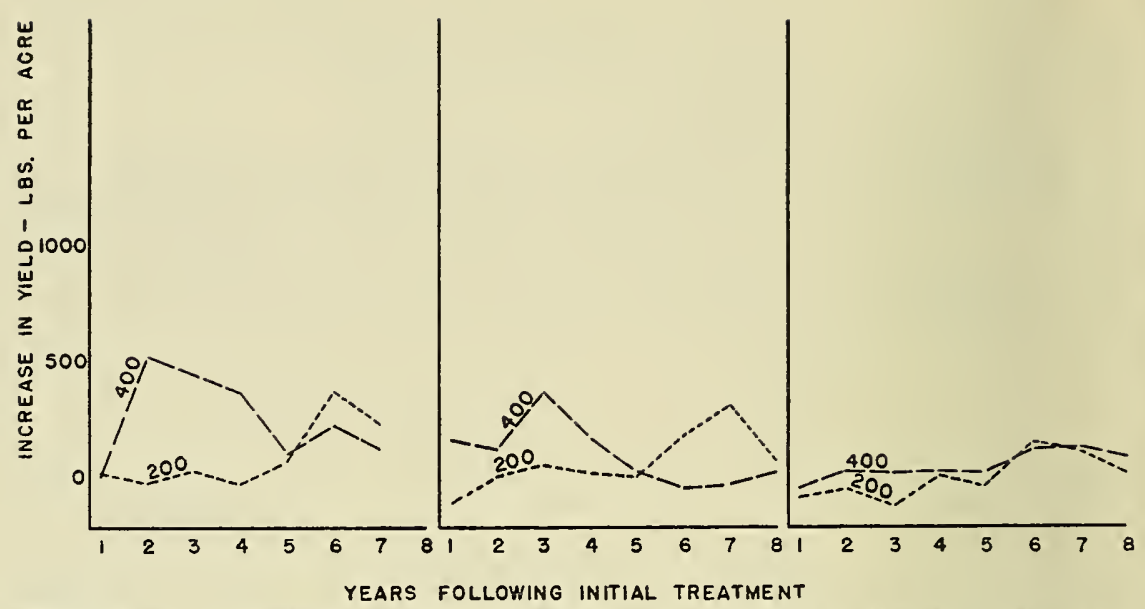

FIGURE 4. Increase in yield of forage resulting from surface applications of 200 pounds of 20 per cent superphosphate every 4 th year and 400 pounds initial application.

\section{AT MODERATE PHOSPHATE LEVELS}

Four treatments were included in which the amount applied averaged 100 pounds of 20 per cent superphosphate per acre per year. The treatments were as follows: 100 pounds every year, 200 pounds every two years, 400 pounds every four years, and 800 pounds in one application at the beginning of the experiment. The results are given in Figure 5.

The data show little difference in either yield or desirable species as a result of difference in application. In only one instance was the difference in yield large enough to be significant. This was with the 800 pound application at Hurricane, and may have been due to the fact that results of only seven years are available.

The yield data by years is given in Figure 6 for each of the areas. The results from the three areas differ somewhat, but there are certain general trends in all three areas. The 800-pound initial application gave the highest yields in all three areas for the first half of the experiment. However, during the latter part of the trial, the yields were consistently lower than for any of the other treatments. This is what might be expected since both fixation and plant absorption probably reduced the supply of available phosphate. Furthermore, there was a higher percentage of undesirable species (broomsedge) in these plots.

Response to all treatments was evident on the Lewisburg and Hurricane plots throughout the experiment. The Wardensville plots showed 


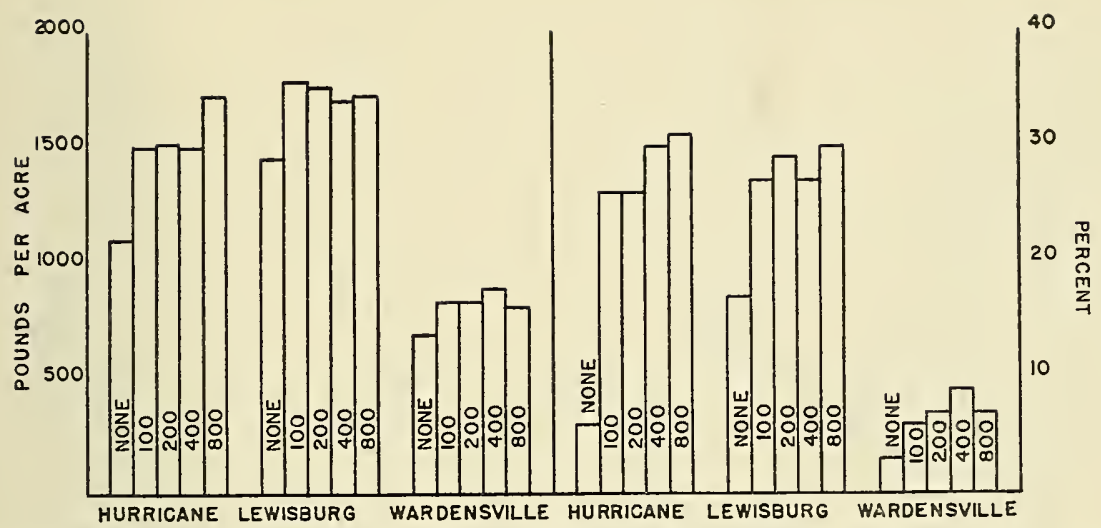

FIGURE 5. Effect of frequency of application of intermediate rates of 20 per cent superphosphate on yield and desirable species in permanent pastures. Rates were none, 100 pounds every year, 200 pounds every two years, 400 pounds every four years, and 800 pounds applied as initial application.

little effect from treatment until 1945, which was a favorable season for pasture in that area.

\section{AT HIGH PHOSPHATE LEVELS}

Two treatments were included in which the average amount applied was 200 pounds of 20 per cent superphosphate (40 pounds $\mathrm{P}_{2} \mathrm{O}_{5}$ ) per acre per year. In these the application rates were 400 pounds of superphosphate every two years and 800 pounds every four years. The results are shown in Figure 7.

The yields at Lewisburg appear to show a slight advantage for the 800-pound application every four years. However, the difference is less than experimental error. The difference at Hurricane in favor of the 400-pound application likewise is slightly less than that required for significance at the 5 per cent level. Comparisons with other plots on these same areas indicate that plot variation is responsible for the differences and there is no real significance associated with frequency of application.

The yearly yield data, during favorable seasons, show a marked effect of each application. For example, in the third year and following the second 400-pound application, there was a marked response at both Hurricane and Lewisburg. Likewise, in the seventh year at Wardensville, the 400-pound application made the previous fall increased the yield, whereas the yield declined on the plots that had an 800-pound application three years previously. (See Figure 8.) 


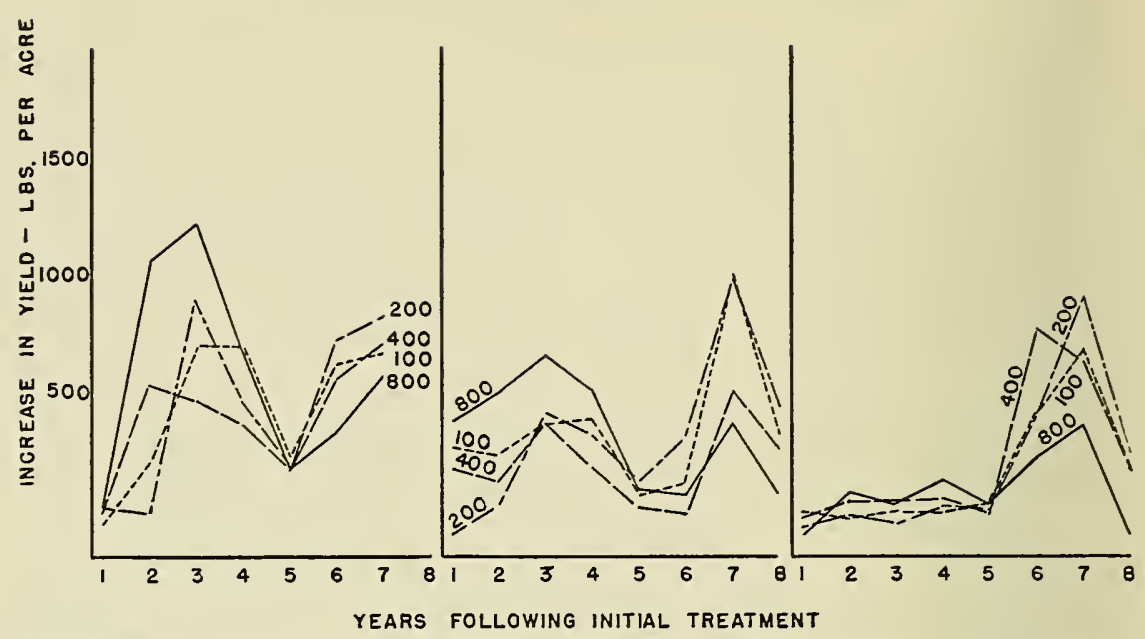

FIGURE 6. Increase in yield of forage resulting from surface applications of 20 per cent superphosphate. Rates used were 100 pounds every year, 200 pounds every two years, 400 pounds every four years, and 800 pounds initially.

YIELD

DESIRABLE SERIES

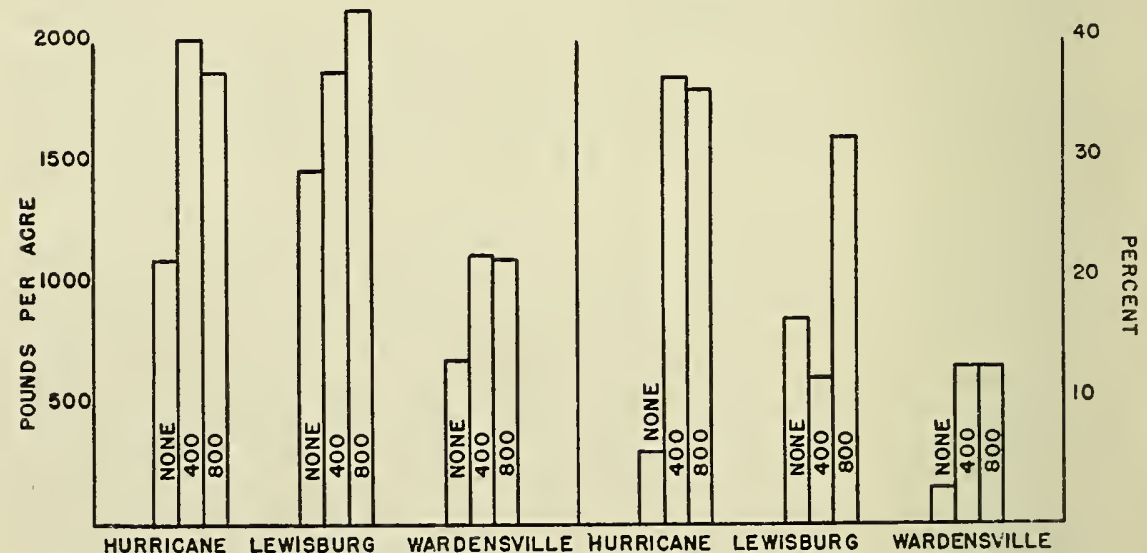

FIGURE 7. Effect of frequency of application of high rates of 20 per cent superphosphate on yield and desirable species in permanent pastures. Applications were none, 400 pounds every two years, and 800 pounds every four years.

The results of all tests indicate that it makes little difference in total yield whether the phosphate is applied frequently (every year) or only at infrequent intervals (eight years). The important factor is the amount of phosphate applied. 


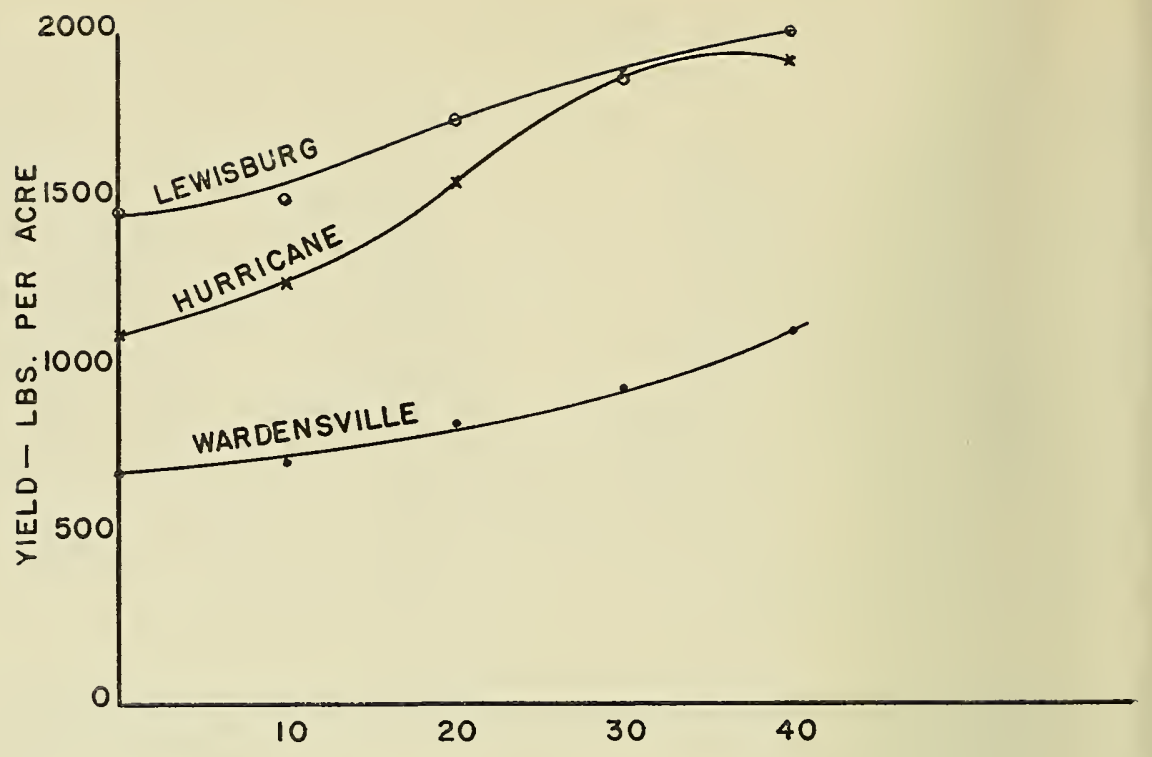

\section{AVERAGE ANNUAL RATE OF $\mathrm{P}_{2} \mathrm{O}_{5}$ APPLICATION LES. PER ACRE}

FIGURE 9. Yield curves for various rates of phosphate application at three locations.

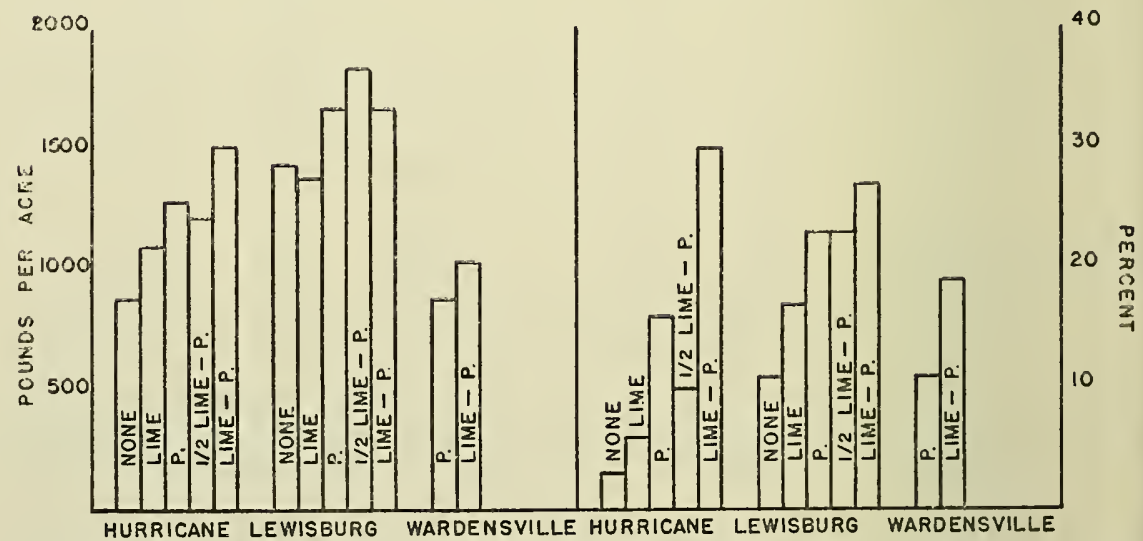

FIGURE 10. Effect of liming on yield and desirable species. Rates of liming used ware (1) $1 / 2$ L-ground limestone to bring surface $11 / 2$ " to $\mathrm{pH} 6.0$, (2) L-ground limestone to bring surface $3^{\prime \prime}$ to $\mathrm{pH} 6.0$, except at Wardensville where lime was applied to bring surface 3 " to $\mathrm{pH} 6.5$. 
227 pounds and desirable species by 3 per cent on the unfertilized area. When applied with phosphate fertilizer, the yield was increased by 217 pounds and the desirable species by 14 per cent. The lower rate of liming on this plot did not increase the yield or desirable species. Actually, the desirable species were slightly lower than on the unlimed plot. This can be accounted for only as plot variation.

The effect of liming on yield was very slight at Lewisburg, where the original $\mathrm{pH}$ was 5.5. None of the differences were large enough to be significant. However, the limed plots had better quality feed than the unlimed areas, as indicated by the higher content of desirable species.

At Wardensville, the addition of lime did not result in a significant increase in yield, but there was considerable increase in desirable species.

\section{Time of Application of Lime and Phosphate}

Four treatments were included to compare spring versus fall applications of lime and superphosphate. The treatments and results are given in Figure 11.

It has been suggested that fall applications of superphosphate might be superior to spring applications because of less rapid fixation during the winter months. The differences found here are so small that there does not appear to be any advantage in average yield from either time of application. Furthermore, yields during the first season after application did not differ enough to favor any particular season of the year for application.

DESIRABLE SPECIES

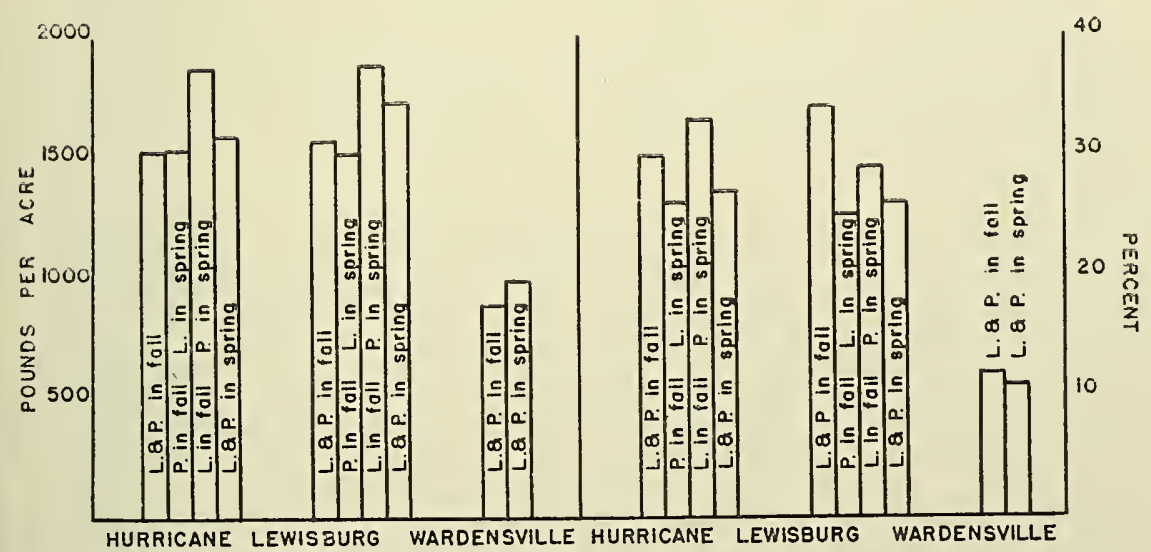

FIGURE 11. Effect of time of application of lime and superphosphate on yield and desirable species. 
There does appear to be an advantage from applying lime some months prior to the application of the superphosphate. At both Lewisburg and Hurricane the highest yields were obtained by this method. On the other hand, applying the phosphate first and the lime later appeared to be just as satisfactory as applying both at the same time. The most important consideration is to be sure that both are applied when needed.

\section{Potash}

Potash was applied at rates of 200 and 400 pounds muriate of potash ( 50 per cent $\mathrm{K}_{2} \mathrm{O}$ ) applied one-half in the fall of 1939 and half in the fall of 1943. The effects of these applications are shown in Figure 12.

YIELD

DESIRABLE SPECIES

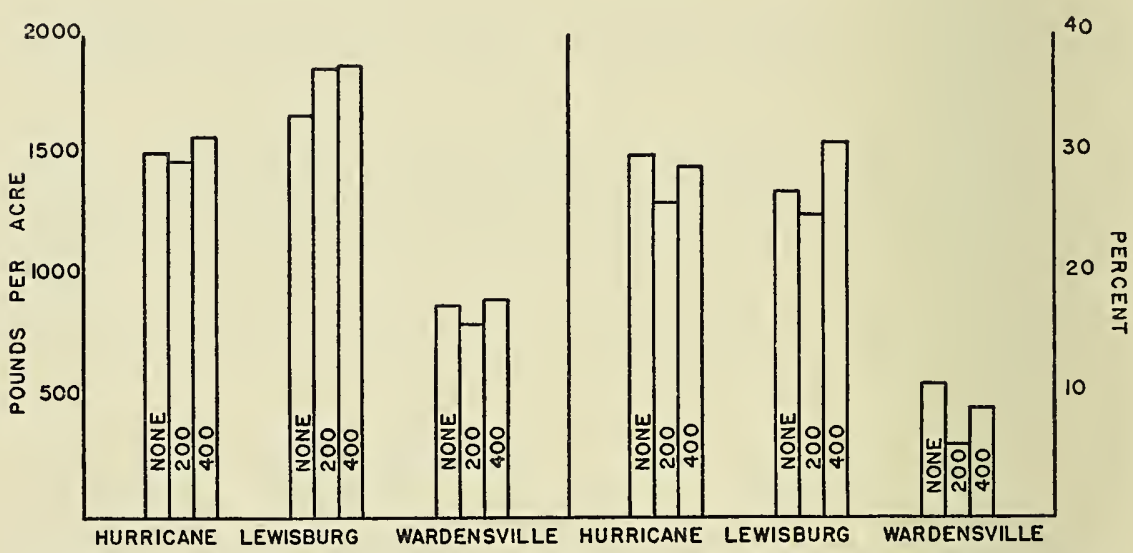

FIGURE 12. Effect of muriate of potash ( 50 per cent $K_{2} O$ ) on yield and desirable species. Rates of application were 200 and 400 pounds per acre applied $1 / 2$ in 1939 and $1 / 2$ in 1943.

There is an indication of some increase in yield as a result of potash applications at Lewisburg, but the differences are not significant. A study of yields by years (Figure 13) shows that potash applications did significantly affect the yield in 1944 and 1945 on those plots. This was just after the second application (fifth and sixth years). It is recognized that potash does not have as great a residual effect as phosphate and it seems probable, in light of these results, that more frequent applications of potash would have resulted in increased yields. There were no differences in annual or average yields due to potash at either Wardensville or Hurricane. 


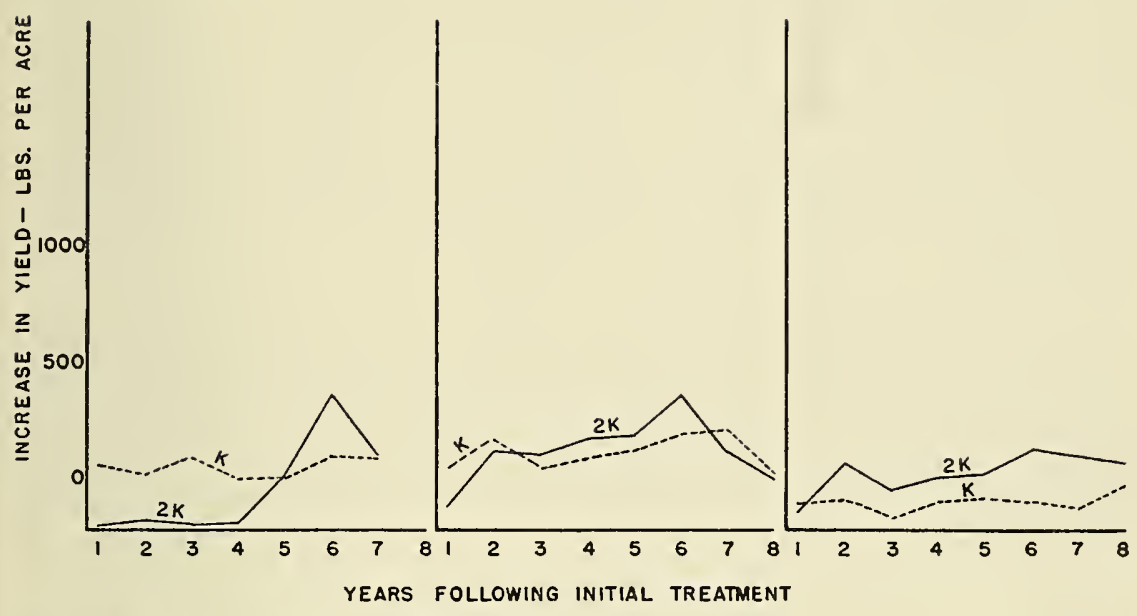

FIGURE 13. Increase in yield following applications of 100 pounds muriate of potash every four years (K) and 200 pounds of muriate of potash every four years $(2 \mathrm{~K})$.

The second application of potash at Hurricane resulted in an apparent increase in the fifth and sixth years or just following the second application on the plots having the 200-pound total application. The yield of these plots averaged below the no-potash plots for the first four years of the experiment.

\section{Discussion}

The evaluation of pasture improvement based only on yield and percentage of desirable species is difficult to translate into terms of financial return. However, it seems desirable to attempt a general evaluation. At present prices it would seem possible to secure superphosphate (20 per cent $\mathrm{P}_{2} \mathrm{O}_{5}$ ) at a cost of not more than $\$ 2.00$ per 100 pounds applied to the land. If the increased yield is given a value of $\$ 20.00$ per ton, an evaluation may be made as shown in Table 2.

The results show that all rates of treatment were highly profitable on the Hurricane plots during the seven years for which results were secured. The greatest return (\$2.21 for each $\$ 1.00$ invested) was for the 1,200-pound application.

At Lewisburg all rates of treatment except the lowest (400 pounds) were profitable, and the greatest return ( $\$ 1.34$ per $\$ 1.00$ invested) was for the 1,600-pound application. 
Table 2. Cost of Fertilizer and Value of Increased Yields per Acre

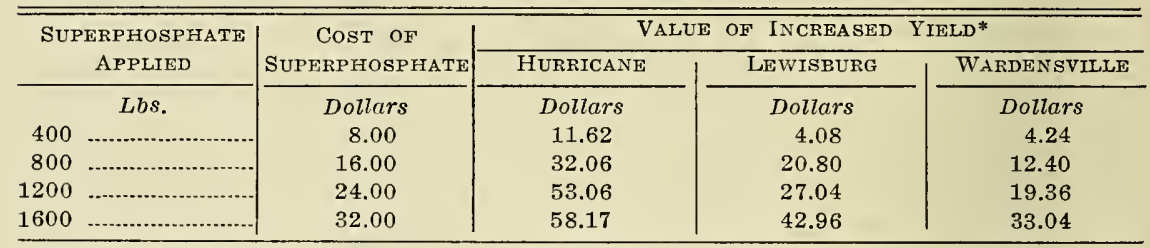

*Based on results of seven years at Hurricane and eight years at Lewisburg and Wardensville.

At Wardensville only the 1,600-pound application gave enough increase to pay for the cost of the fertilizer ( $\$ 1.03$ for the $\$ 1.00$ invested). However, as has been pointed out previously, yields were limited by dry periods during six of the eight years of the experiment and marked increases were obtained in only two years. It is recognized that drought periods during the summer are common in this area but are probably not as severe as during this period where yield was limited three years out of four. In spite of this it is remarkable that the highest rate of application gave increased yields which would pay for the cost of fertilizer.

It should also be noted that the results as reported above do not take into consideration the quality of the herbage harvested. Data in the various figures show that, in all cases, treatment resulted in a higher content of desirable grass and legume species, primarily bluegrass and white clover. It seems reasonable, therefore, to conclude that pasture treatment would increase the value of the herbage and the carrying capacity of the pasture even though total yield was not increased. With the increase in yield, as well as the improved herbage, pasture treatment assumes an ever greater value than can be shown by the simple evaluation attempted.

The experiments reported in this bulletin, as well as those reported in earlier studies $(2,3,4)$, demonstrate the effectiveness of lime and superphosphate in increasing the production of permanent pastures. It is clearly indicated that first consideration should always be given to the application of lime. Not only did lime directly increase production of pasture on acid soils, but also it markedly increased the effectiveness of applied superphosphate fertilizer. This study shows that pasture soils should be limed to a $\mathrm{pH}$ of at least 6.0. Lime should be applied ahead of fertilization, but favorable responses were obtained when lime and superphosphate were applied the same year.

The detailed tests in this study, with their wide range of superphosphate rates and frequencies of application, provide an excellent basis for determining the phosphate needs of West Virginia pastures. 
The data indicate that for most profitable production, permanent pastures should receive at least 40 pounds $\mathrm{P}_{2} \mathrm{O}_{5}$ per acre per year.

The frequency of phosphate application was found to be of far less importance than the total amount applied. This is especially true when only considering yields. However, there are a number of other factors that should be considered when determining the amount and frequencies of application. For example, the data show that small initial applications give much slower response than larger applications. Small applications would require greater frequencies of applying and would thus increase application costs. On the other hand, large, less frequent applications might encourage greater phosphate fixation and also would require greater capital outlay at each application date. For these reasons it would appear that permanent pastures should be top-dressed with adequate phosphate at least every four years but not more frequently than every two years.

\section{Literature Cited}

1. Pierre, W. H., and others, West Virginia Pastures: Types of Vegetation, Carrying Capacity, and Soil Properties. W. Va. Univ. Agr. Exp. Sta. Bull. 280, 1937.

2. Pohlman, G. G., and Cornell, F. D., Jı., Pasture Improvement in Upshur County. W. Va. Univ. Agr. Exp. Sta. Bull. 308, 1943.

3. Robinson, R. R., and Pierre, W. H., Response of Permanent Pastures to Lime and Fertilizers (1930 to 1936). W. Va. Univ. Agr. Exp. Sta. Bull. 289, 1938.

4. Schaller, F. W., Pohlman, G. G., Henderson, H. O., and Ackerman, R. A., Pasture Fertilization Experiments at Reymann Memorial Farm. W. Va. Univ. Agr. Exp. Sta. Bull. 324, 1945. 


